\title{
Progression of kidney disease in type 2 diabetes - beyond blood pressure control: an observational study
}

\author{
David J Leehey*1, Holly J Kramer ${ }^{1,2}$, Tarek M Daoud ${ }^{1}$, Maninder P Chatha ${ }^{1}$ \\ and Majd A Isreb ${ }^{1}$
}

\begin{abstract}
Address: ${ }^{1}$ Departments of Medicine Veterans Affairs Hospital Hines, IL and Loyola University Medical Center Maywood, IL, USA and ${ }^{2}$ Department of Preventive Medicine, Loyola University Medical CenterMaywood, IL, USA

Email: David J Leehey* - dleehey@lumc.edu; Holly J Kramer - hkramer@lumc.edu; Tarek M Daoud - tdaoudmd@direcway.com; Maninder P Chatha - mpchatha@hotmail.com; Majd A Isreb - nephronmd@hotmail.com

* Corresponding author
\end{abstract}

Published: 28 June 2005

BMC Nephrology 2005, 6:8 doi:10.1 186/147/-2369-6-8
Received: 06 November 2004

Accepted: 28 June 2005

This article is available from: http://www.biomedcentral.com/l47/-2369/6/8

(C) 2005 Leehey et al; licensee BioMed Central Ltd.

This is an Open Access article distributed under the terms of the Creative Commons Attribution License (http://creativecommons.org/licenses/by/2.0), which permits unrestricted use, distribution, and reproduction in any medium, provided the original work is properly cited.

\begin{abstract}
Background: The risk factors for progression of chronic kidney disease (CKD) in type 2 diabetes mellitus (DM) have not been fully elucidated. Although uncontrolled blood pressure (BP) is known to be deleterious, other factors may become more important once BP is treated.
\end{abstract}

Methods: All patients seen in the outpatient clinics of our hospital between January 1993 and September 2002 with type 2 DM and clinical evidence of CKD were evaluated. Progression of kidney disease was evaluated by rate of decline of glomerular filtration rate (GFR) as estimated from the simplified MDRD formula. Variables associated with progression in univariate analyses were examined by multivariate analysis to determine the factors independently associated with kidney disease progression.

Results: 343 patients (mean age 69 years; all male; 77\% Caucasian) were studied. Mean BP, glycated hemoglobin, and serum cholesterol during the study period were $138 / 72 \mathrm{mmHg}, 8.1 \%$, and 4.8 $\mathrm{mmol} / \mathrm{L}$, respectively. Mean decline of GFR was $4.5 \mathrm{ml} \mathrm{min-I} 1.73 \mathrm{~m}^{2}-\mathrm{I} \mathrm{yr}-\mathrm{I}$ (range -14 to +32 ). Low initial serum albumin $(p<0.00 \mathrm{I})$, black race $(p<0.00 \mathrm{I})$, and degree of proteinuria $(p=0.002)$, but not blood pressure, glycated hemoglobin, or serum cholesterol, were independently associated with progression.

Conclusion: In a cohort of diabetic patients with CKD in whom mean BP was $<140 / 80 \mathrm{mmHg}$, the potentially remediable factors hypoalbuminemia and proteinuria but not blood pressure were independently associated with progression of kidney disease. Further understanding of the relationship between these factors and kidney disease progression may lead to beneficial therapies in such patients.

\section{Background}

Diabetic nephropathy is the most common cause of endstage kidney disease (ESKD) in the United States and worldwide. Most diabetic patients with ESKD have type 2 diabetes. Since only a minority of type 2 diabetic patients develop kidney disease, predisposing factors for development of the disease are operative. In addition, once clinical kidney disease is evident, the rate of decline of 
glomerular filtration rate (GFR) is highly variable, ranging from 2 to $20 \mathrm{ml} \mathrm{min-1} \mathrm{yr-1} \mathrm{[1].} \mathrm{The} \mathrm{reasons} \mathrm{for} \mathrm{these} \mathrm{dif-}$ ferences in the rate of disease progression are multifactorial, including both non-modifiable and modifiable factors [2,3]. Blood pressure control is known to be important in preventing adverse cardiovascular and renal outcomes in diabetic patients with hypertension [4]. However, it is not clear whether or not blood pressure is an important predictor of GFR decline in diabetic patients with CKD in whom blood pressure is controlled.

The purpose of the present study was to determine the factors independently associated with chronic kidney disease (CKD) progression assessed by rate of decline of GFR in a cohort of male predominantly elderly veteran patients with type 2 diabetes. In this population, in whom BP was generally well controlled, hypoalbuminemia, black race, and degree of proteinuria, but not blood pressure, were associated with disease progression.

\section{Methods \\ Subjects}

A search of the computerized patient record system at Hines VA Medical Center, Hines, Illinois was performed to find all patients seen in the outpatient clinics between January 1993 and September 2002 with type 2 DM and clinical evidence of CKD. Potential subjects were included if they had all of the following: a) type 2 DM [clinical diagnosis and/or glycated hemoglobin > 6.5\%]; b) chronic kidney insufficiency, defined by a persistent elevation of serum creatinine (SCr) level; at least 3 serum creatinine values of $>124 \mu \mathrm{mol} / \mathrm{L}$ with at least a six-month interval between the first and last serum creatinine value were required for inclusion; $c$ ) proteinuria [positive urine dipstick or urine protein $>0.15 \mathrm{~g} / \mathrm{d}$ or urine albumin/creatinine ratio $\geq 30 \mathrm{mg} / \mathrm{g}$ ]. GFR was calculated using the simplified MDRD formula [GFR (ml min-1 $\left.1.73 \mathrm{~m}^{2}-1\right)=$ $186 \times(\mathrm{SCr})^{-1.154} \times(\text { age })^{-0.203} \times(0.742$ if female $) \times(1.210$ if black)][5]. The serum creatinine concentration was not calibrated to MDRD laboratory creatinine values. Patients known to have another cause of kidney disease (e.g., polycystic kidney disease, ischemic nephropathy, or biopsyproven non-diabetic kidney disease) were excluded. In order to determine rate of CKD progression, individual GFR values were calculated from every serum creatinine value between the time when the serum creatinine was first noted to be $>124 \mu \mathrm{mol} / \mathrm{L}$ (baseline value) and either the time of the last available serum creatinine or the commencement of kidney replacement therapy. The rate of GFR decline (slope) (ml min-1 $1.73 \mathrm{~m}^{2}-1 \mathrm{yr}-1$ ) for each patient during the study period was then determined by linear regression analysis using all calculated GFR values. Decline in GFR was represented as a positive value. The mean duration of the study period was 36 months (range
7-149). The mean number of GFR values utilized for slope determination was 14 (range 3-69).

\section{Co-variates}

Information on age, race, weight, height, use of angiotensin converting enzyme (ACE) inhibitors or angiotensin receptor blockers (ARBs), blood pressure, glycated hemoglobin, serum cholesterol, hemoglobin, serum albumin, and urine protein excretion was obtained from the computerized patient record system. Age, weight $(\mathrm{kg})$ and height $(\mathrm{m})$ were defined as the recorded values at the time of the first laboratory creatinine measurement $>124$ $\mu \mathrm{mol} / \mathrm{L}$. Body mass index (BMI) $\left(\mathrm{kg} / \mathrm{m}^{2}\right)$ was then calculated using the weight and height values. Race was selfreported. Blood pressure was measured at each clinic visit by a medical technician or a nurse (generally every 3-6 months) in the seated position using a mercury sphygmomanometer. Glycated hemoglobin was measured by high performance liquid chromatography. Hemoglobin values were measured by Coulter counter. Serum values of creatinine, cholesterol, and albumin were measured by automated analyzer. Urinary protein was measured by the pyrogallol red-molybdate method and urinary albumin by immunoturbidemetry. The degree of proteinuria was classified as mild, moderate, or heavy. Mild proteinuria was defined as dipstick trace- $0.3 \mathrm{~g} / \mathrm{L}$ and/or protein $0.15-$ $0.5 \mathrm{~g} / \mathrm{d}$ and/or spot urine albumin/creatinine ratio of 30$300 \mathrm{mg} / \mathrm{g}$; moderate proteinuria was defined as dipstick $1.0 \mathrm{~g} / \mathrm{L}$ and/or protein $0.5-3.0 \mathrm{~g} / \mathrm{d}$ and/or spot urine albu$\mathrm{min} /$ creatinine ratio of $300-2000 \mathrm{mg} / \mathrm{g}$; and heavy proteinuria was defined as dipstick $3.0 \mathrm{~g} / \mathrm{L}$ and/or protein > $3.0 \mathrm{~g} / \mathrm{d}$ and/or spot urine albumin/creatinine ratio of > $2000 \mathrm{mg} / \mathrm{g}$.

\section{Statistical analysis}

Mean values of systolic blood pressure, diastolic blood pressure, glycated hemoglobin, and serum cholesterol during the study period were computed for each patient and utilized for analysis. Because degree of proteinuria was a categorical variable, maximum degree of proteinuria recorded during the study period was utilized. Since hemoglobin and serum albumin values were expected to decline as kidney disease progressed (see Discussion), initial hemoglobin and serum albumin values (i.e., values obtained closest in time to the beginning of the study period for each patient) were used. Univariate analyses were performed using t-test for continuous variables and Chi-square analysis for categorical variables. Multivariate linear regression analyses using rate of decline (slope) of GFR as the dependent variable were then performed in both age-adjusted and non-age-adjusted fashion using an automated backwards elimination procedure to delete factors with a P-value $>0.15$ from the model one at a time. Multivariate analyses were performed using all variables 
Table I: Demographic and clinical variables in 343 study patients

\begin{tabular}{|c|c|}
\hline Age (years) & $69 \pm 9(43-92)$ \\
\hline Race & 80 black; 263 Caucasian \\
\hline Body mass index $(\mathrm{kg} / \mathrm{m} 2)$ & $30 \pm 5(16-50)$ \\
\hline Initial serum creatinine $(\mu \mathrm{mol} / \mathrm{L})$ & $150 \pm 35(124-389)$ \\
\hline Initial GFR (ml/min/l.73 m²) & $10(13-77)$ \\
\hline Degree of proteinuria (see text) & Group I= II8; Group $2=100 ;$ Group $3=125$ \\
\hline Mean systolic blood pressure $(\mathrm{mmHg})$ & $138 \pm 14(96-189)$ \\
\hline Mean diastolic blood pressure $(\mathrm{mmHg})$ & $72 \pm 8(49-97)$ \\
\hline Treatment with $A C E I / A R B$ & No $=99 ;$ Yes $=244$ \\
\hline Mean serum cholesterol (mmol/L) & $4.8 \pm 1.0(2.3-8.9)$ \\
\hline Mean glycated hemoglobin (\%) & $8.1 \pm 1.6(5.5-17)$ \\
\hline Initial hemoglobin (g/L) & $128 \pm 19(67-179)$ \\
\hline Initial serum albumin (g/L) & $34 \pm 6(17-53)$ \\
\hline
\end{tabular}

Table 2: Univariate association of demographic and clinical variables with decline in GFR

\begin{tabular}{lll}
\hline Variable & $r$ & $P$ \\
\hline Age & -0.192 & 0.002 \\
Race & $*$ & 0.002 \\
Body mass index & -0.010 & 0.859 \\
Initial serum creatinine & -0.137 & 0.055 \\
Degree of proteinuria & $*$ & $<0.001$ \\
Mean systolic blood pressure & 0.107 & 0.048 \\
Mean diastolic blood pressure & 0.136 & 0.012 \\
Treatment with ACEl/ARB & 0.039 & 0.482 \\
Mean serum cholesterol & 0.014 & 0.797 \\
Mean glycated hemoglobin & 0.147 & 0.007 \\
Initial hemoglobin & -0.136 & 0.014 \\
Initial serum albumin & -0.295 & $<0.001$ \\
\hline
\end{tabular}

*categorical independent variables

as well as using only those variables found to be significantly associated with progression on univariate analysis.

Data are expressed as mean $\pm \mathrm{SD}$. All $\mathrm{P}$ values were two sided and a $P$ value of $<0.05$ was used to indicate statistical significance. Statistical analyses were performed using Systat software (SPSS, Chicago, IL).

This study complied with the recommendations of the Declaration of Helsinki and was approved by the local Institutional Review Board.

\section{Results}

Demographic and clinical variables in the 343 patients who met study criteria are given in Table 1 . The mean study period was 36 months (range 7-149). The mean age was 69 (range 43-92) with 73\% of patients aged 65 or older. The majority of patients $(77 \%)$ were Caucasian.
Mean values for blood pressure, glycated hemoglobin, and serum cholesterol during the study period were 138/ $72 \mathrm{mmHg}, 8.1 \%$, and $4.8 \mathrm{mmol} / \mathrm{L}$, respectively. The majority of patients $(71 \%)$ were treated with ACE inhibitors or ARBs.

Mean rate of decline of GFR during the study period was $4.5 \mathrm{ml} \mathrm{min}-11.73 \mathrm{~m}^{2}-1 \mathrm{yr}-1$ (range -14 to +32 ). The variables most highly associated with progression on univariate analysis were lower initial serum albumin and greater degree of proteinuria ( $\mathrm{p}<0.001$ ), followed by younger age and black race $(\mathrm{p}=0.002)$, higher glycated hemoglobin $(\mathrm{p}=0.007)$, higher mean diastolic blood pressure $(\mathrm{p}=0.012)$, lower initial hemoglobin $(\mathrm{p}=0.014)$, and higher systolic blood pressure $(\mathrm{p}=0.048)$ (Table 2$)$. Figures 1 and 2 depict the association between decline in GFR and degree of proteinuria and serum albumin levels, respectively. Patients with greater degrees of proteinuria not unexpectedly had higher rates of disease progression. In addition, the most rapid disease progression was seen in patients with the most profound hypoalbuminemia (serum albumin level $<25 \mathrm{~g} / \mathrm{L}$ ). Rate of progression was only approximately $3 \mathrm{ml}$ min- $1.73 \mathrm{~m} 2-1 \mathrm{yr}-1$ with no relationship between serum albumin and progression once serum albumin levels were $>35 \mathrm{~g} / \mathrm{L}$. 138 patients (40\%) had systolic hypertension ( $\mathrm{BP}=140 \mathrm{mmHg}$ systolic). There was no association between systolic blood pressure and GFR decline when systolic BP was $<140 \mathrm{mmHg}$. However, above that level, rate of GFR decline increased with increasing systolic BP (Figure 3). Only 49 patients $(14 \%)$ had diastolic BP readings of $=80 \mathrm{mmHg}$. The relationship between diastolic BP and GFR decline was Ushaped, with the lowest rate of progression in the 75-79 mmHg range (Figure 4 ).

The following independent variables were considered for selection in the stepwise linear regression, using backwards selection: age, race, systolic BP, diastolic BP, 

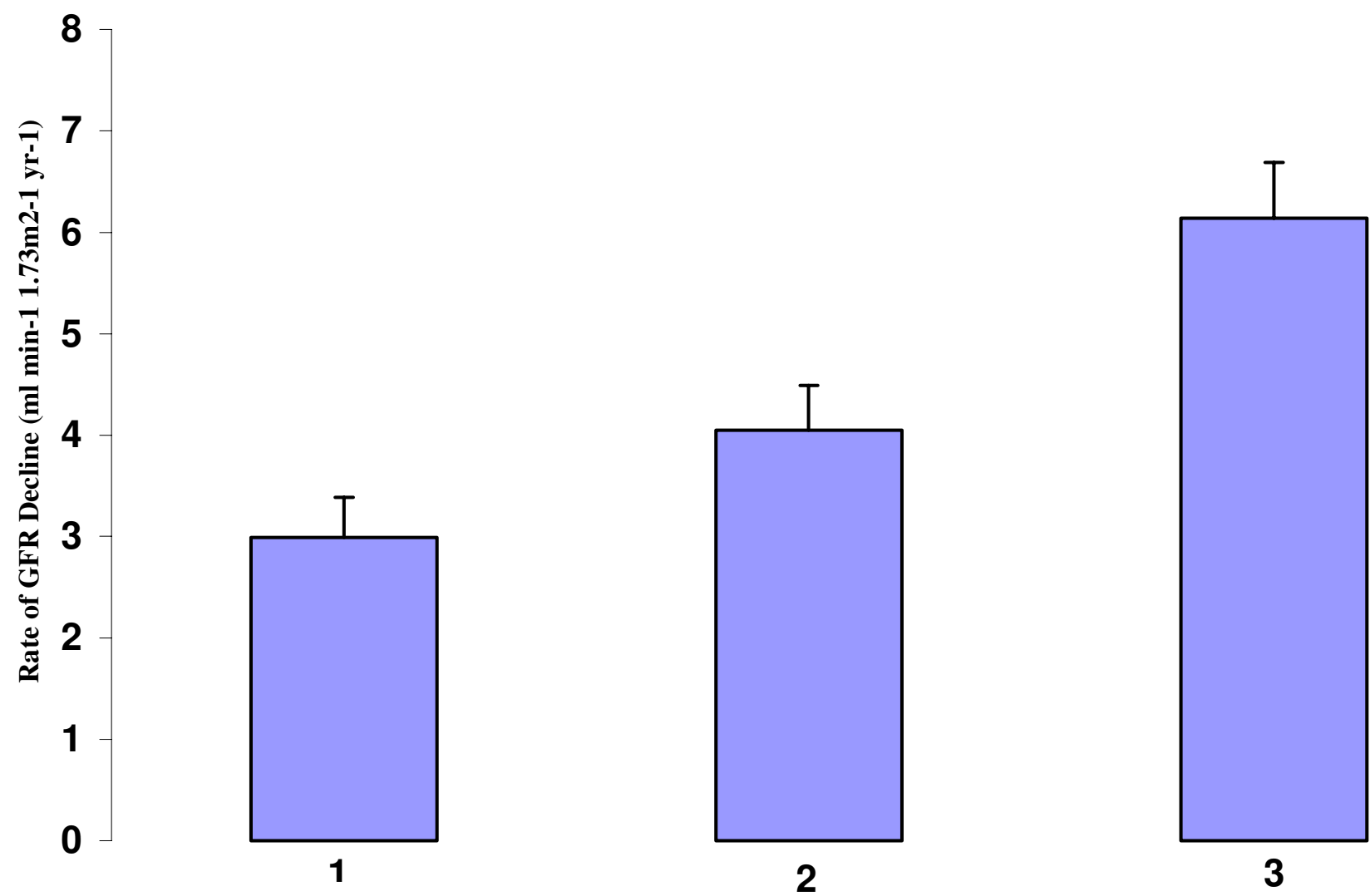

Degree of proteinuria

\section{Figure I}

Relationship between degree of proteinuria and rate of GFR decline ( $I=$ mild proteinuria; 2 = moderate proteinuria; $3=$ heavy proteinuria; see text for definitions)

glycated hemoglobin, degree of proteinuria, initial hemoglobin, and initial serum albumin level. Because of the Ushaped relationship between diastolic BP and GFR decline, (diastolic BP) ${ }^{2}$ was also evaluated. When both diastolic BP and (diastolic BP) ${ }^{2}$ were entered into the regression equation, neither was significantly associated with BP decline $(\mathrm{p}=0.943$ for diastolic BP and $\mathrm{p}=0.935$ for $(\text { diastolic } \mathrm{BP})^{2}$ ). In addition, systolic blood pressure and glycated hemoglobin were not independently associated with progression in this analysis. Lower initial serum albumin, black race, and degree of proteinuria were the only variables independently associated with progression at the $\mathrm{p}<0.05$ level (Table 3 ). Similar results were seen using a non-age-adjusted model (Table 3 ) and when all variables regardless of their association with progression were entered into the regression equations.
As regression diagnostics for data from two of the patients indicated high leverage and one was an outlier (with a Studentized residual of 5.071) in the linear regression model, further analyses were performed excluding these cases. The results were not changed after exclusion of these cases, with initial serum albumin $(\mathrm{p}=0.001)$, proteinuria $(\mathrm{p}=0.002)$ and black race $(\mathrm{p}=0.003)$ the only significant variables independently associated with GFR decline.

\section{Discussion}

The most important finding of this study is that the potentially modifiable factors hypoalbuminemia and proteinuria were strongly and independently associated with kidney disease progression in a mostly elderly male type 2 diabetic population with generally well-controlled blood 


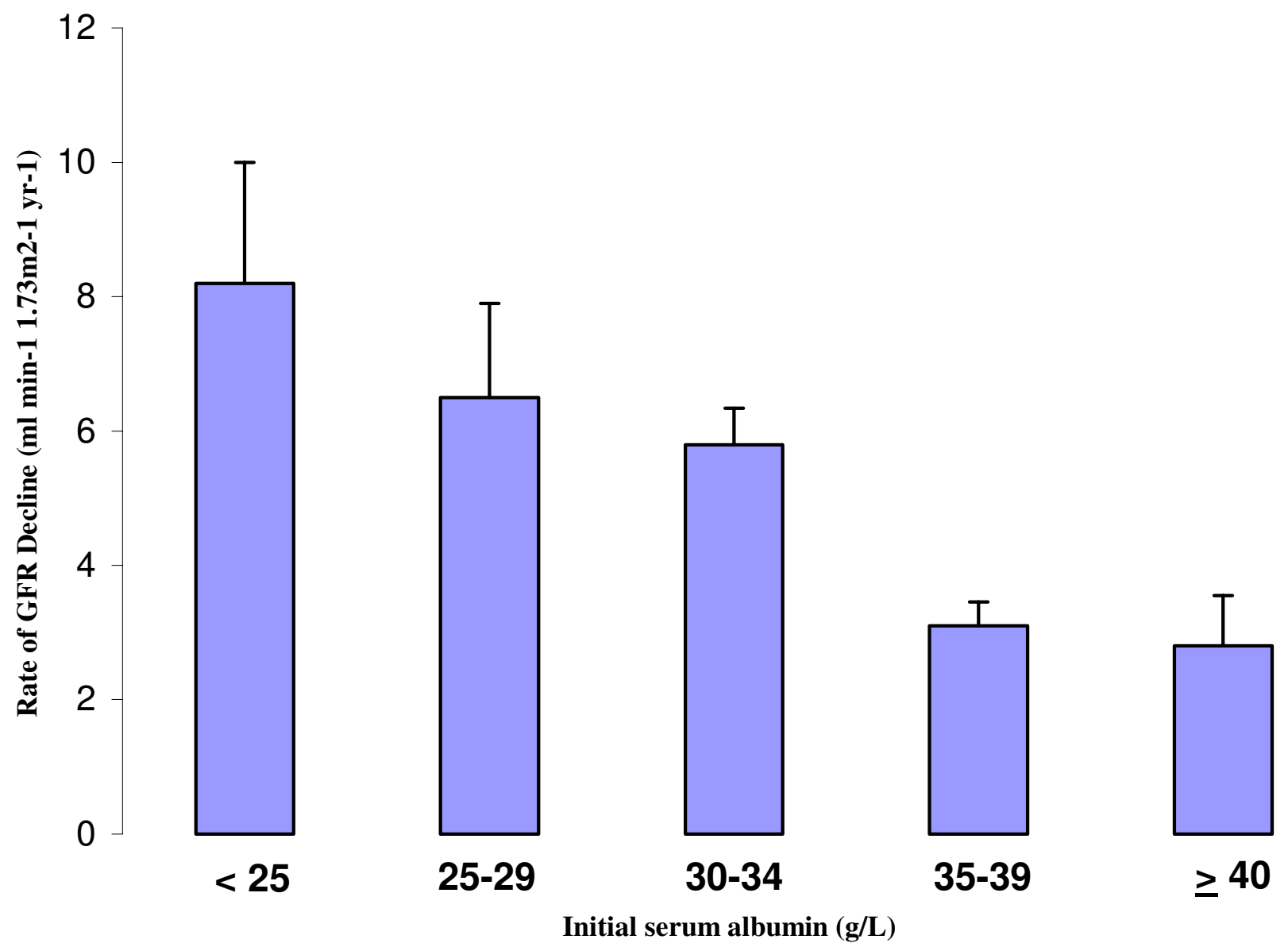

Figure 2

Relationship between initial serum albumin level and rate of GFR decline.

pressure. As shown in Figure 4, there was no effect of systolic BP on progression with systolic BPs $<140 \mathrm{mmHg}$, and diastolic BP had a U-shaped relationship with GFR decline (Figure 4). Therefore systolic BP and both diastolic $\mathrm{BP}$ and (diastolic $\mathrm{BP})^{2}$ were examined in the multivariate regression analyses. In these analyses, there was no independent association between systolic BP or either diastolic BP or (diastolic BP) ${ }^{2}$ and rate of GFR decline in this population.

Blood pressure control is known to be important in preventing adverse cardiovascular and renal outcomes in diabetic patients [4]. However, prospective interventional studies demonstrating slowing of kidney disease progression by blood pressure control were mostly performed in type 1 diabetic patients in whom blood pressure was gen- erally poorly controlled by current standards [6-12] (see Table 4). More recent studies in type 1 and type 2 diabetic patients designed to evaluate the effects of blood pressure control on progression have found lesser effects, either because they were underpowered [13] or possibly because of lower pre-treatment and on-treatment blood pressures $[14,15]$. In support of the latter possibility, in the Reduction of Endpoints in NIDDM with the Angiotensin II Antagonist Losartan (RENAAL) trial, proteinuria, increased serum creatinine, hypoalbuminemia, and anemia at baseline but not baseline blood pressure were predictors of progression [16]. In a recent analysis of RENAAL data, last systolic (but not diastolic) BP prior to end points predicted a higher risk for progressive nephropathy; however, this effect was only seen when systolic BP was $>140$ $\mathrm{mmHg}$ [17]. In a multivariate analysis of data from the 

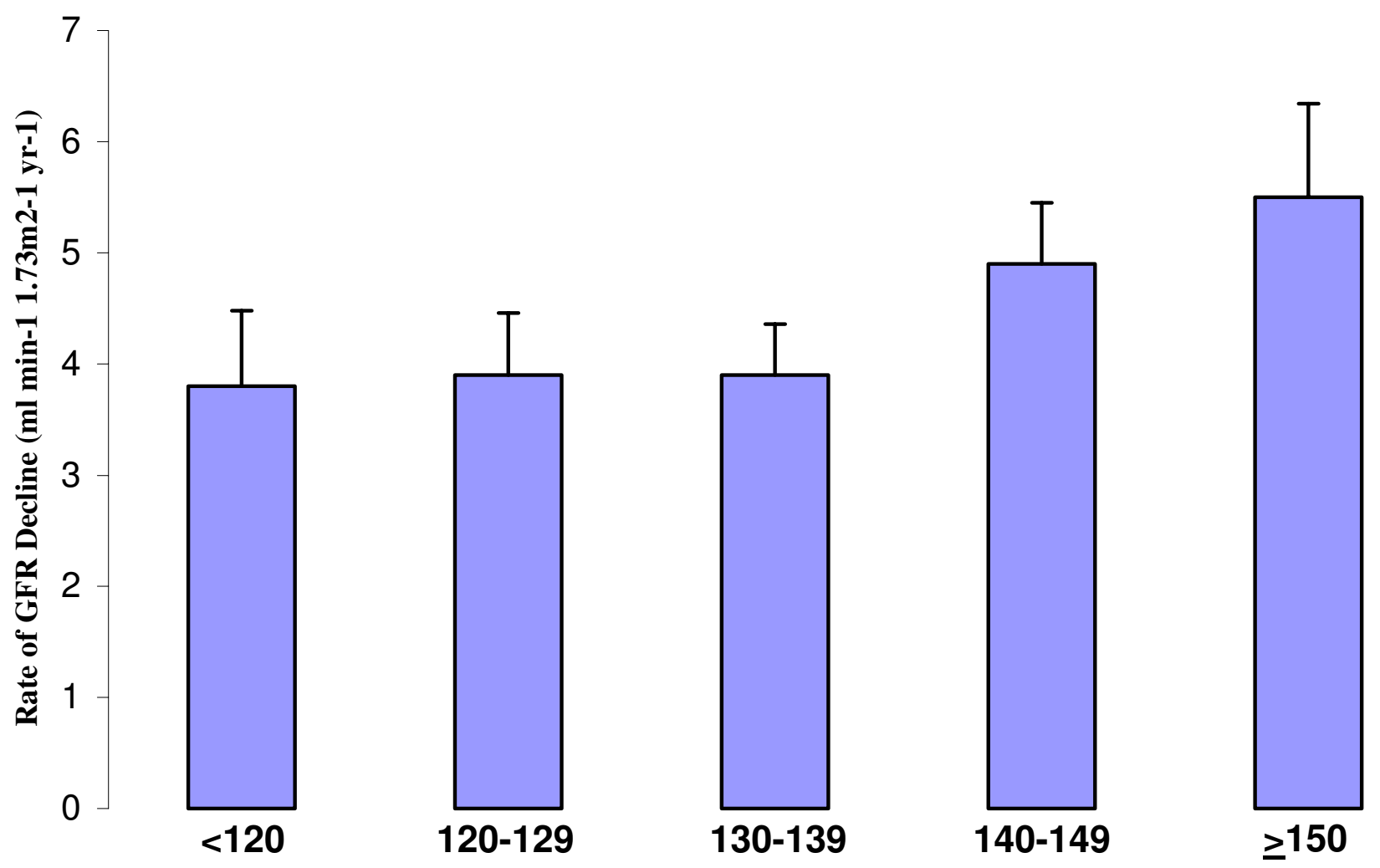

Mean systolic blood pressure (mmHg)

\section{Figure 3}

Relationship between mean systolic blood pressure during the study period and rate of GFR decline.

Irbesartan Diabetic Nephropathy Trial (IDNT), another large clinical trial in type 2 diabetic patients, hypoalbuminemia, increased serum creatinine, albuminuria, decreased hemoglobin, and increased blood pressure were predictors in that order of importance [18]. In the ramipril trial of Lewis et al. there was no significant difference in rate of decline in GFR between two groups of type 1 diabetics with mean arterial blood pressures of $98 \mathrm{vs} .92$ mmHg, respectively [14]. Similarly, in the ABCD trial, a type 2 diabetes trial, there was no benefit of decreasing diastolic blood pressure from $80-89 \mathrm{mmHg}$ to $75 \mathrm{mmHg}$ (difference in actual BPs $138 / 86$ vs. 132/78, or mean arterial blood pressures of 103 vs. $96 \mathrm{mmHg}$ ) [15].

A recent observational study from Japan investigated factors affecting progression of kidney failure in type 2 diabetic patients [2]. These investigators found that lack of insulin therapy, hypoalbuminemia, higher mean blood pressure, and lower hemoglobin at baseline were inde- pendent predictors of kidney failure. However, this study involved only 85 patients and a relatively short survey time (14 months), and disease progression was assessed by time to doubling of serum creatinine. Moreover, the mean arterial blood pressure at baseline was $105 \mathrm{mmHg}$, which is higher than that seen in most recent studies (mean blood pressures during the survey period were not given). In a larger analysis of 227 Caucasian patients with diabetic nephropathy from the Steno Diabetes Center in Denmark, in whom the mean follow-up time was 6.5 years, rate of decline of GFR was predicted by higher values of baseline and mean albuminuria, systolic blood pressure, hemoglobin A1c, and degree of diabetic retinopathy, as well as by baseline GFR, age, lower hemoglobin values, and smoking status during follow-up [3]. In this study, two-thirds of the patients had mean systolic BPs during follow-up of $>149 \mathrm{mmHg}$. In contrast, in our observational study, the mean BP was $138 / 72 \mathrm{mmHg}$ (mean arterial blood pressure $94 \mathrm{mmHg}$ ) during the study 

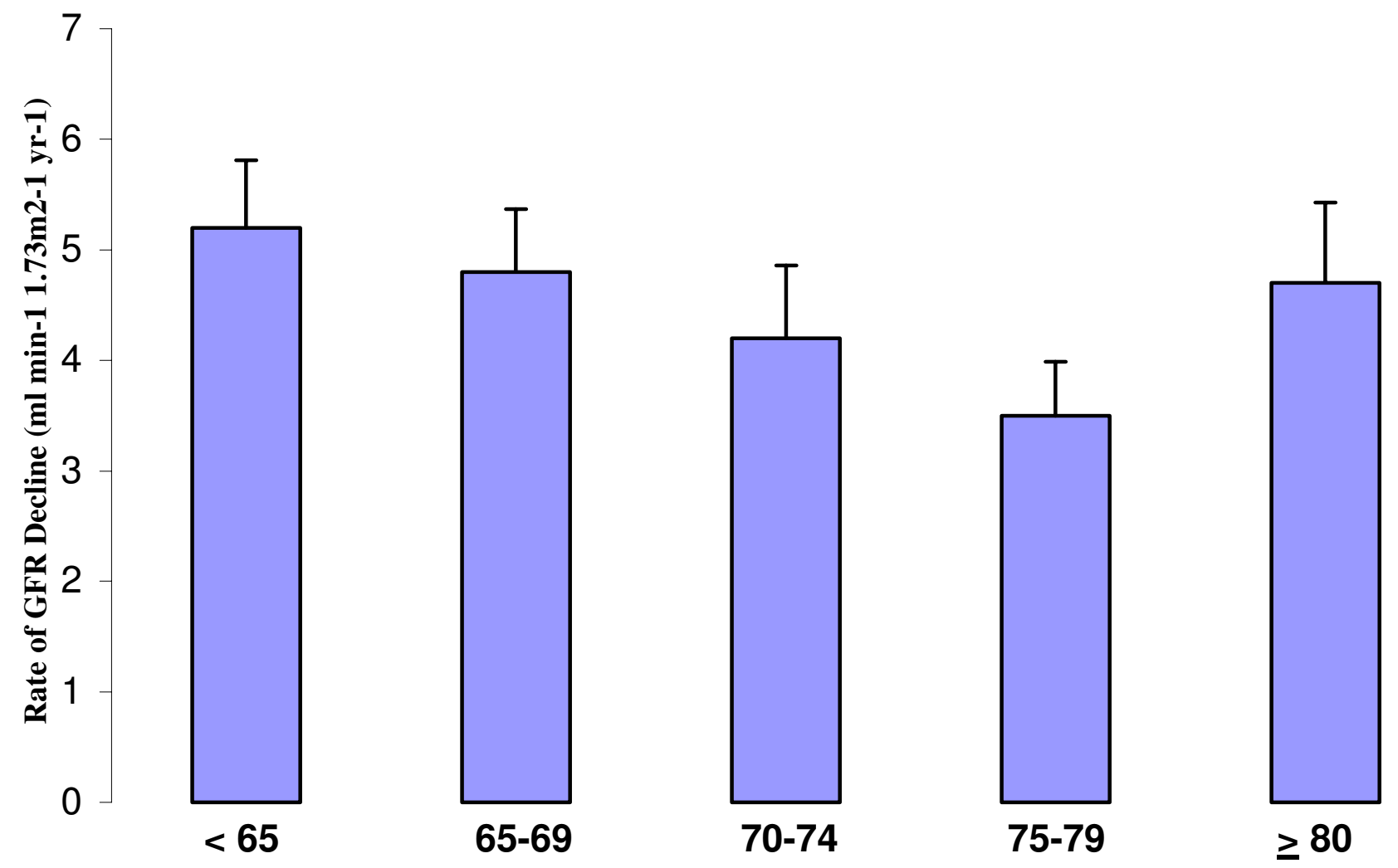

Mean diastolic blood pressure (mmHg)

\section{Figure 4}

Relationship between mean diastolic blood pressure during the study period and rate of GFR decline.

Table 3: Variables independently associated with rate of GFR decline in multivariate linear regression models

\begin{tabular}{lll}
\hline Age-adjusted: & & \\
\hline Variable & F ratio & P value \\
\hline Initial serum albumin & 14.5 & $<0.001$ \\
Black race & 13.2 & $<0.001$ \\
Degree of proteinuria & 10.2 & 0.002 \\
\hline
\end{tabular}

\section{Non-age-adjusted:}

\begin{tabular}{lcc}
\hline Variable & F ratio & $P$ value \\
\hline Initial serum albumin & 15.6 & $<0.001$ \\
Black race & 14.4 & $<0.001$ \\
Degree of proteinuria & 12.8 & $<0.001$ \\
\hline
\end{tabular}

(follow-up) period. This level of BP control was substantially better than that achieved in the Danish study and was also better than that obtained (i.e., 146/76 mmHg) in a recent clinical trial in which a stepped-care algorithm designed to meet American Diabetes Association blood pressure goals of $<130 / 80$ was employed [19]. Thus, taken together, the findings of interventional and observational studies suggest that BP control becomes less important in delaying progression when BP is not very elevated.

The results of our study indicate that hypoalbuminemia independently predicted GFR decline. In a study investigating the relationship between blood pressure and diabetic kidney disease progression, Dillon [20] found that mean serum albumin was associated with decline in GFR. However, since serum albumin could decrease as kidney disease progresses as a consequence of anorexia and malnutrition, this association could be attributed to reverse causality. Using a similar approach to that employed in 
Table 4: Summary of Interventional Studies in Diabetic Patients Examining Effect of Blood Pressure Control on Kidney Disease Progression

\begin{tabular}{|c|c|c|c|}
\hline AUTHOR & STUDY POPULATION & STUDY SIZE/ DURATION & RESULTS \\
\hline Mogensen et al. Br Med J 1982 [6] & $\begin{array}{l}\text { Type I DM } \\
\text { Mean BP I62/I03 } \\
\text { Urinary albumin } 3.9 \mathrm{~g} / \mathrm{d} \\
\text { GFR } 86 \mathrm{ml} \text { min-I } 1.73 \mathrm{~m}^{2}-1\end{array}$ & $\begin{array}{l}\mathrm{N}=5 \\
73 \text { month treatment period } \\
\text { compared to previous } 20-31 \\
\text { month untreated period }\end{array}$ & $\begin{array}{l}\text { BP decreased to } 144 / 95 \mathrm{mmHg} \\
\text { with treatment } \\
\text { Rate of decline of GFR decreased } \\
\text { from I } 4.8 \text { to } 5.9 \mathrm{ml} \text { min- } \mathrm{I} \mathrm{yr}-\mathrm{I} \text { in } \\
\text { treated period }\end{array}$ \\
\hline Parving et al. Lancet 1983 [7] & $\begin{array}{l}\text { Type I DM } \\
\text { Mean BP I } 44 / 97 \mathrm{mmHg} \\
\text { Proteinuria }>0.5 \mathrm{~g} / \mathrm{d} \\
\text { GFR approx } 77 \mathrm{ml} \mathrm{min-I} 1.73 \mathrm{~m}^{2}-\mathrm{I}\end{array}$ & $\begin{array}{l}\mathrm{N}=10 \\
39 \text { month treatment period } \\
\text { compared to } 29 \text { month untreated } \\
\text { period }\end{array}$ & $\begin{array}{l}\text { BP decreased to } 128 / 84 \mathrm{mmHg} \\
\text { with treatment } \\
\text { Rate of decline of GFR decreased } \\
\text { from } 0.9 \text { to } 0.39 \mathrm{ml} \text { min- } \mathrm{I} \text { mo-I in } \\
\text { treated period }\end{array}$ \\
\hline Bjorck et al. Br Med J 1986 [8] & $\begin{array}{l}\text { Type I DM } \\
\text { Mean BP } 163 / 97 \mathrm{mmHg} \\
\text { Mean proteinuria } 2.9 \mathrm{~g} / \mathrm{d} \\
\text { Mean serum } \mathrm{Cr} 2.1\end{array}$ & $\begin{array}{l}\mathrm{N}=14 \\
4.8 \text { yrs ( } 2.8 \text { yrs untreated followed } \\
\text { by } 2 \text { yrs treated with captopril) }\end{array}$ & $\begin{array}{l}\text { BP decreased to } 155 / 94 \mathrm{mmHg} \\
\text { with treatment }(\mathrm{p}<0.02) \\
\text { Urinary protein decreased from } \\
2.9 \text { to } 2.8 \text { (NS) } \\
\text { Rate of decline of GFR decreased } \\
\text { from I } 0.3 \text { to } 5.5 \mathrm{ml} \text { min-I yr-I }(\mathrm{p}< \\
0.02)\end{array}$ \\
\hline Parving et al. Br Med J I987 [9] & $\begin{array}{l}\text { Type I DM } \\
>200 \mathrm{ug} / \mathrm{min} \text { albuminuria } \\
\text { BP I } 43 / 96 \mathrm{mmHg} \text { pre-treatment } \\
\text { Mean GFR approx. } 103 \mathrm{ml} \mathrm{min-I} \\
\text { I.73 } \mathrm{m}^{2} \text {-I }\end{array}$ & $\begin{array}{l}\mathrm{N}=1 \mathrm{I} \\
32 \text { mo. untreated followed by } 6 \text { yrs } \\
\text { treated) }\end{array}$ & $\begin{array}{l}\text { BP decreased to I } 29 / 84 \mathrm{mmHg} \\
\text { with treatment }(\mathrm{p}<0.0 \mathrm{I}) \\
\text { Albuminuria decreased from } 1038 \\
\text { to } 504 \text { ug/min }(\mathrm{p}<0.0 \mathrm{I}) \\
\text { Rate of decline of GFR decreased } \\
\text { from } 0.89 \text { to } 0.22 \mathrm{ml}-\mathrm{I} \text { min-I mo-I } \\
\text { during treatment }(\mathrm{p}<0.0 \mathrm{I})\end{array}$ \\
\hline Parving et al. BMJ 1988 [10] & $\begin{array}{l}\text { Type I DM treated with captopril } \\
\text { or placebo } \\
>0.3 \mathrm{~g} / \mathrm{d} \text { albumin (mean approx. } \\
0.95 \text { ) } \\
\text { Baseline BP I } 46 / 93 \mathrm{mmHg} \text { and } \\
137 / 95 \mathrm{mmHg} \text { in } 2 \text { groups, } \\
\text { respectively } \\
\text { Serum } \mathrm{Cr}<120 \mu \mathrm{mol} / \mathrm{L} \\
\text { GFR mean approx. } 97 \mathrm{ml} \text { min-I } \\
\text { I.73 } \mathrm{m}^{2}-\mathrm{I}\end{array}$ & $\begin{array}{l}\mathrm{N}=31 \\
\text { Captopril }(\mathrm{N}=18) \text { Control }(\mathrm{N}= \\
13) \\
2.5 \text { yrs }\end{array}$ & $\begin{array}{l}\text { MAP decreased by } 8.7 \mathrm{mmHg} \text { to } \\
\text { I } 36 / 85 \text { by captopril; increased by } \\
6.6 \mathrm{mmHg} \text { to } 145 / 98 \mathrm{mmHg} \text { in } \\
\text { controls }(\mathrm{p}<0.00 \mathrm{I}) \text { Albumin } \\
\text { excretion decreased to } 390 \mathrm{ug} / \mathrm{min} \\
\text { in captopril, increased to } 1367 \mathrm{ug} / \\
\text { min in controls }(\mathrm{p}<0.00 \mathrm{I}) \\
\text { GFR decline } 5.8 \mathrm{ml} \text { min-I } \mathrm{yr}-\mathrm{I} \text { in } \\
\text { captopril vs. } 10 \mathrm{ml} \text { min- } \mathrm{yr}-\mathrm{I} \text { in } \\
\text { controls }(\mathrm{p}<0.0 \mathrm{I})\end{array}$ \\
\hline $\begin{array}{l}\text { Sawicki et al J Diabetes } \\
\text { Complications I995 [II] }\end{array}$ & $\begin{array}{l}\text { Type I DM } \\
\text { Proteinuria }>0.5 \mathrm{~g} / \mathrm{d} \\
\text { Serum } \mathrm{Cr}<265 \mu \mathrm{mol} / \mathrm{L} \\
\text { Diabetic retinopathy } \\
\mathrm{BP}>140 / 90 \mathrm{mmHg} \text { or need for BP } \\
\text { meds } \\
\text { Intensive treatment including BP } \\
\text { self-monitoring with goal BP }< \\
140 / 90 \mathrm{mmHg}(\mathrm{IT}) \text { vs. routine } \\
\text { treatment }(\mathrm{RT})\end{array}$ & $\begin{array}{l}\mathrm{N} \sim 100 \\
5 \text { yrs }\end{array}$ & $\begin{array}{l}\text { Primary study endpoints (need for } \\
\text { dialysis or death) decreased in IT } \\
\text { group }\end{array}$ \\
\hline UKPDS 38199813 & $\begin{array}{l}\text { Type II DM } \\
\text { Serum } \mathrm{Cr}<177 \mu \mathrm{mol} / \mathrm{L} \\
\mathrm{BP}<150 / 85 \mathrm{mmHg} v \mathrm{ss} .<180 / 105 \\
\mathrm{mmHg}\end{array}$ & $\begin{array}{l}\mathrm{N}=31 \text { with overt nephropathy }(> \\
300 \mathrm{mg} / \mathrm{l} \text { albuminuria) } 8.4 \mathrm{yrs}\end{array}$ & $\begin{array}{l}\text { Insufficient numbers to determine } \\
\text { if } B P \text { control benefitted patients } \\
\text { with overt nephropathy }(P=0.06)\end{array}$ \\
\hline $\begin{array}{l}\text { Trocha et al. J Hypertension } 1999 \\
\text { [12] }\end{array}$ & $\begin{array}{l}\text { Type I DM } \\
\text { Proteinuria }>0.5 \mathrm{~g} / \mathrm{d} \\
\mathrm{Cr}<265 \mu \mathrm{mol} / \mathrm{L} \\
\text { Diabetic retinopathy } \\
\text { BP }>140 / 90 \mathrm{mmHg} \text { or need for BP } \\
\text { meds } \\
\text { BP self-monitoring with goal BP }< \\
\text { I } 40 / 90 \text { (IT) vs. routine care (RT) }\end{array}$ & $\begin{array}{l}N=91 \\
\text { IT }(N=45) \\
\operatorname{RT}(N=46) \\
10 \text { yrs }\end{array}$ & $\begin{array}{l}\text { Primary study endpoints (need for } \\
\text { dialysis or death) decreased in IT } \\
\text { group }\end{array}$ \\
\hline $\begin{array}{l}\text { Lewis et al. Am J Kidney Dis } 1999 \\
\text { [14] }\end{array}$ & $\begin{array}{l}\text { Type I DM with overt nephropathy } \\
\text { Serum } \mathrm{Cr}<354 \mu \mathrm{mol} / \mathrm{L} \\
\text { MAP of } 92 \mathrm{mmHg} \text { (Group I) vs. } \\
\text { 102-107 } \mathrm{mmHg} \text { (Group II) }\end{array}$ & $\begin{array}{l}N=129 \\
N=63 \text { in Group I } \\
N=66 \text { in Group II } \\
2 \text { yrs }\end{array}$ & $\begin{array}{l}\text { MAP } 92 \mathrm{mmHg} \text { in Group I vs. } 98 \text { in } \\
\text { Group II } \\
\text { No significant difference in rate of } \\
\text { decline of GFR } \\
\text { Significant decrease in albuminuria } \\
\text { in intensive group }\end{array}$ \\
\hline
\end{tabular}


Table 4: Summary of Interventional Studies in Diabetic Patients Examining Effect of Blood Pressure Control on Kidney Disease Progression (Continued)

\begin{tabular}{|c|c|c|c|}
\hline $\begin{array}{l}\text { Estacio et al. Diabetes Care } 2000 \\
\text { [15] }\end{array}$ & $\begin{array}{l}\text { Type II DM } \\
\text { DBP }>90 \mathrm{mmHg} \\
\text { CCr of } 76 \mathrm{ml} \text { min-I I.73 } \mathrm{m}^{2}-\mathrm{I} \\
\text { Randomized to intensive therapy } \\
\text { (IT) (DBP }<75 \mathrm{mmHg} \text { ) or } \\
\text { moderate therapy (MT) (DBP } 80- \\
89 \mathrm{mmHg} \text { ) }\end{array}$ & $\begin{array}{l}N=470 \text { total } \\
N=83 \text { with overt proteinuria } \\
5 \text { yrs }\end{array}$ & $\begin{array}{l}\text { BP decreased significantly with IT } \\
\text { vs. MT (I32/78 } \mathrm{mmHg} \text { vs. I38/86 } \\
\mathrm{mmHg}) \\
\text { Pts with overt albuminuria } \\
\text { demonstrated a steady decline in } \\
\text { creatinine clearance of } 5-6 \mathrm{ml} \text { min- } \\
\text { I I.73 } \mathrm{m}^{2}-1 \text { yr-I throughout the } \\
\text { follow-up period in both IT and } \\
\text { MT groups (pNS) }\end{array}$ \\
\hline
\end{tabular}

*categorical independent variables

our study, Ueda et al. [2] reported that baseline serum albumin was a predictor of the development of ESKD in Japanese patients with type 2 diabetes. This study used reciprocal creatinine and/or the development of ESKD as endpoints rather than GFR decline; moreover, the population was quite different from the predominantly Caucasian U.S. male veterans examined in our study. Nevertheless, these data, in conjunction with the RENAAL and IDNT data, in which hypoalbuminemia was also an independent predictor of progression in type 2 diabetes, support the relationship between hypoalbuminemia and GFR decline.

Why would hypoalbuminemia be predictive of kidney disease progression? One possibility is that the serum albumin level reflects the degree of proteinuria, a known risk factor for progression in most kidney diseases, including diabetes [3,21-27]. However, this is not the sole explanation for the association between serum albumin level and disease progression, because hypoalbuminemia is significantly associated with GFR decline after adjustment for the effects of proteinuria. Since many patients with CKD have evidence of chronic inflammation, as reflected by elevated C-reactive protein (CRP) levels, anemia of chronic disease, and elevated D-dimer and vonWillebrand factor levels [28-30], it is possible that hypoalbuminemia may reflect an inflammatory state, which may increase kidney disease progression [30], possibly by causing oxidative stress [31]. In addition, decreased GFR may result in accumulation of proinflammatory compounds (such as advanced glycated end-products and oxidation products) with resultant hypoalbuminemia [32] and kidney injury [33]. The hypothesis that low serum albumin reflects an inflammatory state, which contributes to progression of kidney disease is supported by recent studies in both non-diabetic [34,35] and diabetic [36] populations.

As has been done by other investigators $[2,16,18]$, we utilized initial serum albumin levels in our analyses rather than mean values during the treatment period. Of note, when mean serum albumin values were utilized, there was also a strong association between serum albumin and decline in GFR (data not shown). However, we believed that this could be due to a "reverse" association, as progression of renal failure could result in decreased protein intake, malnutrition, and a decrease in serum albumin level. We also chose to use initial values for hemoglobin rather than mean values during the treatment period. This was done because of the well known direct association between anemia and lower GFR due to erythropoietin deficiency. Mean values of other continuous variables (such as blood pressure) were utilized in order to better capture treatment effects during the observation period and to enhance the precision of the analysis by utilizing many measurements of each variable.

We included patients who had the diagnosis of diabetes mellitus and/or mean glycated hemoglobin values $>6.5 \%$ in our analysis. We did not utilize blood glucose values for study inclusion or for analysis since it was not always possible to determine if a sample was a fasting or random sample. We did not find an association between blood glucose control (as reflected by glycated hemoglobin) and progression in our study. The role of hyperglycemia in progression of nephropathy in type 2 diabetes is not clear, in large part because many studies have lacked statistical power. However, in post-hoc analyses of two large clinical trials, RENAAL [16] and IDNT [18], baseline glycated hemoglobin was not an important predictor. However, in their observational study, Rossing et al. [3] recently reported that mean glycated hemoglobin was associated with GFR decline. The lack of association between serum cholesterol and progression in our study is consistent with these other studies $[3,16,18]$.

The observational nature of our study does have limitations. For instance, there was no control over the type of medication used for hypertension, nor any control over diabetes management or dietary intake. We utilized a formula to estimate rate of GFR decline instead of performing direct clearance measurements. The formula utilized, 
namely the four-variable MDRD estimate, was developed from a largely non-diabetic patient population. Moreover, this formula loses accuracy when the GFR is $>60 \mathrm{ml} \mathrm{min-}$ $11.73 \mathrm{~m}^{2}-1$ and/or if the serum creatinine concentration is not calibrated to MDRD laboratory creatinine values [37]. However, our analysis is based on rate of decline of GFR (slope analysis) and not absolute values of GFR and most patients had baseline GFR values of $<60 \mathrm{ml}$ min-1 $1.73 \mathrm{~m}^{2}-1$. Moreover, the National Kidney Foundation currently recommends using this prediction equation to calculate GFR and monitor progression of kidney disease [5]. Indeed, using rate of GFR decline as our outcome variable has advantages over the doubling of serum creatinine utilized in many prospective clinical trials. This is because doubling of serum creatinine reflects a progressively smaller absolute GFR decline as the serum creatinine increases. Finally, the nature of the kidney disease in our mostly elderly diabetic patients probably represented a mix of diabetic glomerulosclerosis, hypertensive nephrosclerosis, and, in some cases, possibly undiagnosed ischemic nephropathy, either alone or in combination. We did not analyze data on retinopathy since it was not always available in our computerized database. We also did not analyze the relationship between kidney disease progression and cardiovascular disease. Despite these limitations, we believe that our findings are relevant to usual clinical practice.

\section{Conclusion}

The results of our study may have important clinical implications. Although blood pressure control is undeniably important in delaying progression of kidney disease in hypertensive diabetic patients, attention to other potentially remediable factors may be more important in delaying progression once BP is effectively treated. Antiproteinuric agents (such as ACE inhibitors and ARBs) may exert beneficial actions beyond those due to BP control. In addition, the finding that hypoalbuminemia is independently associated with progression of CKD due to type 2 diabetes after adjustment for the effects of proteinuria suggests the possibility that inflammation (and/or malnutrition) may be a progression promoter. In particular, further understanding of the role of inflammation in CKD may lead to therapies which favorably affect kidney disease progression in type 2 diabetic patients.

\section{Competing interests}

The author(s) declare that they have no competing interests.

\section{Authors' contributions}

DJL conceived and designed the study, supervised data collection, carried out the statistical analyses, and prepared the manuscript. HJK assisted in statistical analyses and manuscript preparation. TMD, MPC, and MAI collected data and prepared the spreadsheet for data analysis.

\section{Acknowledgements}

The authors would like to thank John Rotta and Guichan Cao for their assistance with informatics and statistical analysis. Domenic Reda, Ph.D., Acting Director of the Hines Cooperative Studies Program Coordinating Center, gave helpful advice on presentation of the results of this study.

\section{References}

I. American Diabetes Association: Nephropathy in Diabetes. Clinical Practice Recommendations. Diabetes Care 2004, 27(Suppl I):S79-83.

2. Ueda $H$, Ishimura $E$, Shoji $T$, et al.: Factors affecting progression of renal failure in patients with type 2 diabetes. Diabetes Care 2003, 26:1530-1534.

3. Rossing K, Christensen PK, Hovind P, Tarnow L, Rossing P, Parving $\mathrm{H}-\mathrm{H}$ : Progression of nephropathy in type 2 diabetic patients. Kidney Int 2004, 66: 1596-1605.

4. Bakris GL: The importance of blood pressure control in the patient with diabetes. Am J Med 2004, I I 6(Suppl 5A):30S-38S.

5. National Kidney Foundation: K/DOQI Clinical Practice Guidelines for Chronic Kidney Disease Evaluation, Classification, and Stratification. Am J Kidney Dis 2002, 39:S76-92.

6. Mogensen CE: Long-term antihypertensive treatment inhibiting progression of diabetic nephropathy. Br Med J (Clin Res Ed) 1982, 285(6343):685-688.

7. Parving HH, Andersen AR, Smidt UM, Svendsen PA: Early aggressive antihypertensive treatment reduces rate of decline in kidney function in diabetic nephropathy. Lancet 1983 , I (8335): I I75- I I 79.

8. Bjorck S, Nyberg G, Mulec H, Granerus G, Herlitz H, Aurell M: Beneficial effects of angiotensin converting enzyme inhibition on renal function in patients with diabetic nephropathy. $\mathrm{Br}$ Med $J$ (Clin Res Ed) 1986, 293(6545):47I-474.

9. Parving HH, Andersen AR, Smidt UM, Hommel E, Mathiesen ER, Svendsen PA: Effect of antihypertensive treatment on kidney function in diabetic nephropathy. Br Med J (Clin Res Ed) 1987, 294(6585): | 1443-1447.

10. Parving HH, Hommel E, Smidt UM: Protection of kidney function and decrease in albuminuria by captopril in insulin dependent diabetics with nephropathy. BMJ 1988 297(6656): |086-109|.

II. Sawicki PT, Muhlhauser I, Didjurgeit U, Berger M: Effects of intensification of antihypertensive care in diabetic nephropathy. $J$ Diabetes Complications 1995, 9(4):315-317.

12. Trocha AK, Schmidtke C, Didjurgeit $U$, et al.: Effects of intensified antihypertensive treatment in diabetic nephropathy: mortality and morbidity results of a prospective controlled 10 year study. J Hypertens 1999, I7( I0): 1497-1503.

13. UK Prospective Diabetes Study Group: Tight blood pressure control and risk of macrovascular and microvascular complications in type 2 diabetes: UKPDS 38. BMJ 1998, 3 I7:703-7|3.

14. Lewis JB, Berl T, Bain RP, Rohde RD, Lewis EJ: Effect of intensive blood pressure control on the course of type I diabetic nephropathy. Collaborative Study Group. Am J Kidney Dis 1999 , 34:809-817.

15. Estacio RO, Jeffers BW, Gifford N, Schrier RW: Effect of blood pressure control on diabetic microvascular complications in patients with hypertension and type 2 diabetes. Diabetes Care 2000, 23(Suppl 2):B54-64

16. Keane WF, Brenner BM, De Zeeuw D, RENAAL Study Investigators, et al.: The risk of developing end-stage renal disease in patients with type2 diabetes and nephropathy: The RENAAL Study. Kidney Int 2003, 63: I499-1507.

17. Bakris GL, Weir MR, Shanifar S, RENAAL Study Group, et al.: Effects of blood pressure level on progression of diabetic nephropathy: results from the RENAAL study. Arch Intern Med 2003, 163:1555-1565.

18. Middleton JP, Lewis J, for the Collaborative Study Group: Predictors of renal outcome in type 2 diabetic nephropathy [abstract]. J Am Soc Nephrol 2002, 13:249-250. 
19. Tomlinson JW, Owen KR, Close CF: Treating hypertension in diabetic nephropathy. Diabetes Care 2003, 26:1802-1805.

20. Dillon Jj: The quantitative relationship between treated blood pressure and progression of diabetic renal disease. Am J Kidney Dis 1993, 22:798-802.

21. Yokoyama H, Tomonaga O, Hirayama M, et al.: Predictors of the progression of diabetic nephropathy and the beneficial effect of angiotensin-converting-enzyme inhibitors in NIDDM patients. Diabetologia 1997, 40:405-4II.

22. Breyer JA, Bain P, Evans JK, et al.: Predictors of progression of renal insufficiency in patients with insulin-dependent diabetes and overt diabetic nephropathy. Kidney Int 1996, 50:165I-1658

23. Gall M-A, Nielsen FS, Smidt UM, et al.: The course of kidney function in type 2 (non-insulin-dependent) diabetic patients with diabetic nephropathy. Diabetologia 1993, 36:107|-1078.

24. Nelson RG, Bennett PH, Beck GJ, et al:: Development and progression of renal disease in Pima Indians with non-insulindependent DM. N Engl J Med 1996, 335:1636-1642.

25. Klein R, Klein BE, Moss SE, Cruickshanks KJ, Brazy PC: The 10-year incidence of renal insufficiency in people with type diabetes. Diabetes Care 1999, 22:743-75I.

26. Massy ZA, Khoa TN, Lacour B, Deschamps-Latshca B, Man NK Jungers $P$ : Dyslipidaemia and progression of renal disease in chronic renal failure patients. Nephrol Dial Transplant 1999, 1 4:2392-2397.

27. Ruggenenti $P$, Remuzzi G: The role of protein traffic in the progression of renal diseases. Annu Rev Med 2000, 5 I:3 I 5-327.

28. Sarnak MJ, Poindexter A, Wang SR, et al.: Serum C-reactive protein and leptin as predictors of kidney disease progression in the Modification of Diet in Renal Disease Study. Kidney Int 2002, 62:2208-22I5.

29. Stenvinkel P, Heimburger O, Paultre F, et al:: Strong association between malnutrition, inflammation, and atherosclerosis in chronic renal failure. Kidney Int 1999, 55:1899-191I.

30. Kim SB, Yang WS, Park JS: Role of hypoalbuminemia in the genesis of cardiovascular disease in dialysis patients. Perit Dial Int 1999, 19(S2):SI 44- I 49.

31. Himmelfarb J, Stenvinkel P, Ikizler TA, Hakim RM: The elephant in uremia: oxidant stress as a unifying concept of cardiovascular disease in uremia. Kidney Int 2002, 62:1524-1538.

32. Witko-Sarat $\mathrm{V}$, Friedlander M, Nguyen Khoa T, et al.: Advanced oxidation protein products as novel mediators of inflammation and monocyte activation in chronic renal failure. J Immunol 1998, 161:2524-2532

33. Pereira BJ, Shapiro L, King AJ, Falagas ME, Strom JA, Dinarello CA Plasma levels of IL-I beta, TNF alpha and their specific inhibitors in undialyzed chronic renal failure, CAPD, and hemodialysis patients. Kidney Int 1994, 45:890-896.

34. Stuveling EM, Hillege HL, Bakker SJ, Gans RO, Dejong PE, DeZeeuw $D$ : C-reactive protein is associated with renal function abnormalities in a non-diabetic population. Kidney lnt 2003, 63:654-66I.

35. Menon V, Wang X, Greene T, et al:: Relationship between Creactive protein, albumin, and cardiovascular disease in patients with chronic kidney disease. Am J Kidney Dis 2003 42:44-52.

36. Navarro JF, Mora C, Macia M, Garcia J: Inflammatory parameters are independently associated with urinary albumin in type 2 diabetes mellitus. Am J Kidney Dis 2003, 42:53-6I.

37. Poggio ED, Wang X, Greene T, Van Lente F, Hall PM: Performance of the Modification of Diet in Renal Disease and CockcroftGault equations in the estimation of GFR in health and in chronic kidney disease. J Am Soc Nephrol 2005, 16:459-466.

\section{Pre-publication history}

The pre-publication history for this paper can be accessed here:

http://www.biomedcentral.com/1471-2369/6/8/prepub
Publish with Biomed Central and every scientist can read your work free of charge

"BioMed Central will be the most significant development for disseminating the results of biomedical research in our lifetime. "

Sir Paul Nurse, Cancer Research UK

Your research papers will be:

- available free of charge to the entire biomedical community

- peer reviewed and published immediately upon acceptance

- cited in PubMed and archived on PubMed Central

- yours - you keep the copyright

Submit your manuscript here:

http://www.biomedcentral.com/info/publishing_adv.asp
BiolMedcentral 